\title{
Teachers, researchers, but not innovators? Rethinking university-industry collaboration
}

\author{
Heléne Lundberg \\ Department of Business Administration, Mid-Sweden University, Östersund, Sweden, and \\ Christina Öberg \\ CTF Service Research Center, Karlstad University, Karlstad, Sweden and The Ratio Institute, Stockholm, Sweden
}

\begin{abstract}
Purpose - Universities, when collaborating with industry, are generally assumed to be the motors for innovation. Inspired by a case on a university's collaboration with small- and medium-sized enterprises (SMEs) in a regional strategic network (RSN), this paper aims to put forth how the university makes important contributions through transferring knowledge on innovation processes that is a teaching role, rather than sees itself as the party producing innovations. This paper describes and discusses the university's teaching role and its consequences in university-industry collaborations for innovation.

Design/methodology/approach - Empirically, the paper departs from a mid-Swedish RSN where nine SMEs started to work with a university. Interviews with representatives of the nine SMEs participating in the innovation project, along with university and RSN representatives, comprise the main data source. The paper analyzes the university's teaching role and the consequences of it.

Findings - Findings point at how the SMEs developed structured innovation processes, improved their market intelligence and increased their efficiency in providing new solutions. The university facilitated knowledge, while the SMEs responded through creating knowledge both on how to innovate and in terms of innovations.

Originality/value - The teaching role, which would mean that the university stays with one of its core functions, indicates a need to rethink university-industry collaboration related to expectations and role division. Moving from producing innovations to facilitating knowledge on how to innovate, would, for universities, mean that they minimize those conflicts emerging from their various roles and indicate that the production of innovation is placed at those devoted to run and grow businesses.
\end{abstract}

Keywords Innovation, SME, University, University-industry collaboration, Regional strategic networks

Paper type Research paper

\section{Introduction}

This paper takes its motivation from empirical observations of a university's collaboration with small- and medium-sized enterprises (SMEs) in a regional strategic network (RSN), and how the university's role was that of transferring knowledge on - or teaching - innovation processes to be practiced among the receiving SMEs, rather than the university itself producing innovations or founding new businesses. This observation becomes interesting once it is put against the prevailing role of universities in university-industry collaborations, namely, that of creating new ideas and businesses (Bercovitz and Feldman, 2006). The universities' role in developing innovations and businesses has been questioned as it may not lead to any success of such endeavors (Wonglimpiyarat and Yuberk, 2006; Brostrom et al., 2021; Compagnucci and Spigarelli, 2020) and as it collides with the core functions of universities: teaching and researching (Thursby and Thursby, 2011). Still, it remains extensively practiced.

The current issue and full text archive of this journal is available on Emerald Insight at: https://www.emerald.com/insight/0885-8624.htm

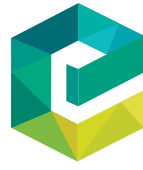

Journal of Business \& Industrial Marketing 36/13 (2021) 161-173

Emerald Publishing Limited [ISSN 0885-8624] [DOI 10.1108/JBIM-03-2020-0126]
While our observation is embedded in a specific setting, it spurred us to ask: should universities rather focus on their core functions also related to innovation? Or more precisely: should they focus on teaching in their relation to innovation? These rhetorical questions are handled in the paper through the purpose of describing and discussing the university's teaching role and its consequences in university-industry collaborations for innovations.

The paper makes the following contributions: to research on university-industry collaboration related to innovations, the emphasis on the university's teaching role is unique. Previous research has foremost focused on the startup journey of universitybased research, and more recently, the triple helix model of innovation and open innovation initiatives (Etzkowitz and Leydesdorff, 2000; Gassmann et al., 2010), including incumbent firms' collaboration with universities. While the broader literature on university-industry collaborations contains training as one aspect of such collaborations (Ankrah and Omar, 2015), this is not

(C) Heléne Lundberg and Christina Öberg. Licensed re-use rights only

The authors are grateful to the Editors and Reviewers for their reviews and comments. Their suggestions for further improvement of the paper were clear and constructive.

Received 1 March 2020

Revised 17 July 2020

9 November 2020

9 April 2021

24 May 2021

Accepted 6 June 2021 
connected to innovation. Empirically, the particularity of university-industry collaborations, including $\mathrm{RSNs}$ and universities' collaborations with SMEs, does not seem to be wellcovered in previous research and does not seem to include the RSN/SME perspective (Christensen, 1997, in Corral de Zubielqui et al., 2015; Miller et al., 2016; Rosendo-Rios et al., 2016). In response to these gaps and in addition to our main focus on theorizing universities' teaching role in innovation, we thereby make an empirical contribution through addressing universityRSN collaborations from multiple perspectives, including university and SME/RSN informants.

The rest of the paper is structured as follows: after this introduction, a theory section elaborates on RSNs and university-industry collaborations related to innovations and knowledge. This is followed by the method section, describing how data was captured and analyzed for the university-RSN collaboration. The findings section follows thereafter. The case is then analyzed and the paper ends with conclusions, including managerial implications and ideas for further research.

\section{Theoretical background}

\section{Setting the stage: Regional strategic networks and} small- and medium-sized enterprises

Inspired by successful regions such as the Silicon Valley (Saxenian, 1990), and to support business development and innovation, there are initiatives to foster collaboration among firms within administrative regions (Malecki, 2007; Huggins and Johnston, 2009). When a leading firm performing an integrating function (Lorenzoni and Baden-Fuller, 1995) is lacking, such initiatives often take the form of RSNs (Lundberg and Johanson, 2011; Eklinder-Frick and Åge, 2017). An RSN describes an initiative to foster business development or innovation by facilitating interactions among its constituents. From interactions among RSN firms, it is assumed that business relationships will develop to overcome various types of resource constraints through the development of new resource combinations (Möller and Rajala, 2007). Furthermore, the RSNs may facilitate access to public funding for innovation initiatives (Guercini and Tunisini, 2017). While being a formalized network in the sense of the RSN being constructed rather than evolving from business interaction (Möller and Rajala, 2007), the degree of governance is often limited, as the participating firms keep their independence and contract businesses on their own.

Firms in RSNs are often SMEs. The importance of SMEs for regional and national economies is undisputed. Still, they often act under pressure from international competition, which means that there is a need for knowledge development if they are to stay competitive. This knowledge development includes enhanced capabilities to create new ideas or innovations (Rothaermel and Hess, 2007; Zhou and Wu, 2010). Separating SMEs into hightech and SMEs-for-life firms means accepting that firms may be small or medium-sized for different reasons and with a wastefully different orientation to business development and innovation. The high-tech SMEs may spin out from universities, whereas the SMEs-for-life may have a history of family ownership, traditional or dated industrial products and engage with only a limited number of business partners (Lundberg and Öberg, 2021). These latter SMEs typically have rather limited innovation capabilities and funding resources for innovation initiatives.
While the idea with RSNs is to foster business creation in general and innovation in particular, many studies show that RSNs fail in these regards. The RSNs rarely become anything more than social hubs; that is, the RSNs do not lead to business relationships or innovation creation (Eklinder-Frick et al., 2011; Andrésen et al., 2012; Eklinder-Frick, 2015). Previous research has discussed how commitment and policies affect the RSN initiatives (Eklinder-Frick et al., 2011; Andrésen et al., 2012; Eklinder-Frick, 2015). Andrésen et al. (2012), for instance, state how the RSN should preferably consist of firms with complementary rather than competing resources, while social goals would be important to establish the RSN as a unit for future development. Eklinder-Frick et al. (2014) relate social capital - the value embedded in social bonds - to innovativeness in RSNs and conclude that social capital positively promotes the development of innovations in the RSNs, while Eklinder-Frick (2015) describes how policies for innovation in RSNs may actually hinder such developments.

Research has, thus, pointed out the difficulties of achieving business relationships among firms in an RSN, and to some extent, how innovations may be enabled or disabled in them. Focus suggests being innovative as the result of resource combinations (Andrésen et al., 2012). Descriptions of collaborations between RSNs and universities seem to be lacking in previous research, and studies on SMEs' collaboration with universities point at such collaboration to be a challenging task for many reasons (Bjerregaard, 2009), including institutional distance with different norms, time frames and outcome expectations (Cyert and Goodman, 1997; Hughes et al., 2009). Such studies have pointed at how some sort of social interaction may be needed to develop trust (Corral de Zubielqui et al., 2015) and transfer tacit knowledge (Cohen and Levinthal, 1990; Agrawal, 2001; Boschma, 2005). Meanwhile, previous studies have shown how universities rather support large firms (Laursen and Salter, 2004; Cunningham and Link, 2015). SMEs, and especially the smaller firms, are, in other words, less likely to take part in university-industry innovation collaborations (Corral de Zubielqui et al., 2015).

Universities' roles in innovation processes with industry While there may be multiple reasons for universities to collaborate with industry (Alexander et al., 2011; Bessant et al., 2012; Ankrah and Omar, 2015; Cunningham and Link, 2015), the development of innovation is a central task. Technology transfer offices have long been at the heart of such operations (Friedman and Silberman, 2003; Siegel et al., 2003; Bercovitz and Feldman, 2006), implying that the university is the party facilitating new ideas to industry in terms of new innovations and firms (Aaboen et al., 2016; Aaboen et al., 2017; LaageHellman et al., 2019). Incubators and science parks constitute but few institutions in this regard (Friedman and Silberman, 2003; Soetanto and Jack, 2013). Following the introduction of the open innovation phenomenon (Gassmann et al., 2010; Öberg and Alexander, 2019), the initial focus on the spin out of ideas from the university (Miranda et al., 2018; Mathisen and Rasmussen, 2019) has been complemented by incumbent firms approaching universities with their problems (Moilanen et al., 2015). The universities would here play the role of playground innovation ideator and develop ideas that fit the particular circumstances of these firms (Etzkowitz and Leydesdorff, 2000; Striukova and Rayna, 2015; Miller et al., 2016). Such 
innovation initiatives, in turn, move toward market-driven rather than technology-pushed innovations, where moving further in such endeavors would include customers at multiple roles for innovation and thereby a loosening of roles compared to traditional expectations (Von Hippel, 2001; Öberg, 2010).

While innovation has come to increasingly be shaped with new role distributions (Heirati and Siahtiri, 2019; Gao et al., 2020), universities are still in any innovation-focused collaboration with industry seen as the motor for innovations. This takes the shape of startups being formed based on research findings and the facilitation of new ideas related to the triple helix model of innovation and open innovation initiatives (Etzkowitz and Leydesdorff, 2000; Lundberg, 2013). Meanwhile, research has pointed out how such activities are not entirely successful (Wonglimpiyarat and Yuberk, 2006), how universities may offer something not needed by the firms (Ankrah and Omar, 2015) and how the collaborations collide with the core functions of universities, namely, teaching and research (Thursby and Thursby, 2011). To partly deal with the issues of pure technology-push innovations, research and practice have recently moved into contextualized innovations, such as adjusting triple helix initiatives to specific market conditions (Asheim and Coenen, 2006; Cai, 2015) or as acknowledged in the broader innovation literature: the development of innovation in tandem with the context (Garud et al., 2014) and the transfer of innovations from one context to a new (Benner and Tushman, 2003).

\section{Framing the topic: Knowledge in university-industry collaborations}

Related to the industrial marketing and purchasing approach, Gressetvold (2001) elaborates on how resources are mobilized, combined, developed and managed in interactions between parties (Gadde, 2004; Baraldi et al., 2012). Mobilization refers to how a party makes resources viable for the other party, combination to how interacting parties both contribute resources that once brought together may change in their characteristics, development to how they change in character ("improve") and managed resources to how the parties warrant the resources to ensure their performative characteristics. Knowledge would be a specific type of resource (Penrose, 1959) and refers to the understanding of something including facts, skills or objects (Nonaka and Takeuchi, 1995). Knowledge as facts describes a party's ability to repeat a known state (knowledge that) and distinguishes knowledge as skills (knowing how) (Blackler, 1995; Cook and Brown, 1999; Xu et al., 2014), which is manifested in how someone practices the knowledge or transfers it to another context. Relating knowledge to innovation and the descriptions of universityindustry collaborations, SMEs and RSNs, the focus tends to be on knowledge as objects (de Wit-de Vries et al., 2019) that is the new idea or product. With this follows that the parties (beyond the university) may not extend their skills in how to innovate but only represent their resources in any such collaboration (Thorpe et al., 2005). Knowledge as skills focuses on knowing and thereby parties' extended abilities (Blackler, 1995; Nonaka and von Krogh, 2009), which would mean that the parties learn how to better innovate.

Research and teaching as the core functions of universities (Thursby and Thursby, 2011) have traditionally dealt with knowledge development and transfer related to facts (Ball et al., 2008). Teaching has come to increasingly focus on skill development and shared learning experiences, rather than lecturing only (Bager, 2011). The teacher's role has thereby partially turned from expert to coach (Snihur et al., 2021). Watfa and Audi (2015) refer to dynamic lecture notes including student feedback, online video repository instead of lectures and social networking as an around-the-hour teacherstudent portal to denote increased activation of students. Specifically related to universities teaching know-how on innovations to entrepreneurship students (Linton and $\mathrm{Xu}$, 2021), the activation and changed roles have been practiced using such methods as design thinking (Glen et al., 2015; John et al., 2020), where Berbegal-Mirabent et al. (2020) and others describe university-industry collaborations through how company representatives partake in the teaching. The activation of students, flipped-classroom pedagogy and design thinking are examples that change the teaching at universities. They, in the sense of focusing on skills rather than facts, close the circle to ambitions of intellectual developments but become more oriented to a future in the industry than one in academia. The changing roles particularly related to entrepreneurship teaching also mean that the teaching approaches an assumed practice; that is, how firms work with innovation or innovate while providing a structure of specific methods of thinking, which may benefit firms not engaging heavily in innovations, but which at the universities are directed at students in entrepreneurship.

The activation of students and innovation methods thus moves toward knowledge as skills. If returning to knowledge as mobilized, combined, developed and managed (Gressetvold, 2001) and integrating this with knowledge as facts and skills (i.e. knowledge that and knowledge how), parties may, as suggested in the prevailing literature on RSNs and university collaborations, just put forth their resources or as the consequence of the university taking on a teaching role, enhance their innovation skills. With the focus on a university's teaching role and its consequences in university-industry collaborations for innovations, we, therefore, ask:

- How can the university's teaching role in universityindustry collaborations be understood?

- What are the consequences of the university taking on a teaching role for innovation?

\section{Research design}

Our findings are based on qualitative empirical research in the form of a case study as this allows for in-depth investigations and descriptions of contemporary phenomena within their real-life contexts (Pettigrew, 1973; Yin, 1994) and promotes understanding of the dynamics (Eisenhardt, 1989) of interaction and collaboration. Case study research is a flexible method, which is considered a strength in capturing the multifaceted and evolving nature of interactions (Dubois and Araujo, 2004). It has, therefore, been recommended as especially suited for research in a network context (Halinen and Törnroos, 1998; Halinen and Törnroos, 2005). Further, which is essential, based on this paper's positioning, case studies allow for finding out circumstances not initially under investigation (Welch et al., 2011) and exploring the consequences of phenomena under study. 
The case study is about nine SMEs that are part of an RSN with 34 members. These nine SMEs participated in a project initiated by the RSN supported by public funding aiming at business development and innovation in collaboration with a university. The SMEs are located in a region with sparse resources and are widely distributed over a large geographical area, creating difficult conditions for their mutual interaction (Persson et al., 2011). The university was contracted for this project after a bidding procedure. Its representatives have an interest in developing their knowledge on innovation processes among SMEs for research and applied purposes (Glen et al., 2015; John et al., 2020).

Parts of the RSN (with the 34 members) have recently been investigated in another research project focusing on family firms in an RSN, facilitating access to the RSN and conducting interviews for this particular study. It was knowledge of the RSN that drove our attention to how it had recently started collaborating with a university, which inspired us to conduct additional interviews to capture this phenomenon and write this paper. The previous study constructs a baseline toward which we compare the university's inclusion in the collaboration and the nine SMEs' development before and since the university project was started. Any study of networks has to handle boundary issues (Halinen and Törnroos, 1998). In this case, all the SMEs taking part in the RSN-university collaboration are part of the data collection, and we investigate the collaboration from three points of view, namely, the university's, the individual SMEs' and the RSN's.

\section{Data collection}

Multiple sources of information were used to gather data from the RSN coordinator, the innovation project leader, each SME participating in the project and university representatives. The main form of data collection was semi-structured, open-ended interviews, which allowed for engaging the participants in a conversation, adding more detailed, follow-up questions when necessary (McCracken, 1988; Yin, 1994) and following interesting themes forward not necessarily predefined by the study (Welch et al., 2011). The first interviews were conducted with the RSN coordinator and the innovation project leader to gain an overview of the project's origin, structure and content. Thereafter, the SME informants were contacted. For the interviews, in line with the recommendations of Huber and Power (1985), the most knowledgeable respondents were asked for, and in all cases, the choice seemed to be self-evident for the SMEs. Using single key informants for each firm is likely to pose limits to our understanding. However, those firms at hand being SMEs and knowledge of such firms' strategies and operations tending to be in the hands of one or a few key managers meant that the informants accurately captured firm perspectives. For practical reasons (vast geographical distances), telephone interviews were conducted. All interviews were audio-recorded and transcribed, and therefore, direct quotes can be presented (translated from Swedish).

Further information about the firms and the interviews is provided in Table 1. As shown in Table 1, almost all firms have been active for decades. Although they have tried to keep up with technical improvements, several informants expressed a need for renewal and improved innovation capability.
The interviews were outlined as follows: to start with, broad questions about the informant's view on the RSN initiative and the university collaboration were addressed. Next, the interview was framed around topics including motives for taking part in the project, the SME's experience of participating in university collaborations and the outcome experienced so far. More precisely, informants were asked to explain the nature and consequence of the facilitated activities related to the university collaboration, including their degree of participation in and evaluation of the seminar series on innovation processes and other project events. Questions concerned what had been learned from these activities, how that had possibly changed the SME's way of conducting business related to business development, innovations and interactions with others in the RSN and what performative consequences the project had had for the SME. This was repeated for each interview and followed up with individual questions depending on answers and particular firm characteristics. In addition to interviews with the SMEs and RSN representatives, two university professors were interviewed. These interviews focused on the same types of topics but from the university's perspective. These informants were also asked to describe their motives for participation, the actions created so far and their views on the outcomes. The project under study was at an early stage and still ongoing at the time of the interviews, which reduced the risk of memory distortion (Huber and Power, 1985; Nutt, 1986). Obviously, the project still being ongoing also constrains the findings of the study to present states (updated during the revision process) of the SMEs. Such limitations would primarily be seen in how the project may lead to more actual innovations among the SMEs, while we presently rather capture their knowledge on innovating. Still, we see the balance between conducting research in real time and risks of retrospective rationalizations as a fine line with benefits and constraints and how the present state helps to capture phenomena that have previously not been well-researched.

In addition to interviews, the SMEs' and the RSN's websites were used as sources of secondary data until November 2020, which provided access to interviews and descriptions made at the time that events occurred. Based on these sources of information, following Pettigrew (1997), a case description in chronological order was developed for each firm. As data collection and analysis partly occurred concurrently, ongoing changes and the identification of new issues of relevance for the study were included in both the data capturing and analysis.

\section{Data analysis}

The data analysis is based on content analysis in line with the process outlined by, for instance, Miles and Huberman (1984), namely, data reduction initiated by within-case analyzes for each firm, followed by explanation-building attempts and cross-case analyzes focusing on recurrent themes and patterns, as well as similarities and differences; data displays in tables; and conclusions drawn based on aspects deemed to be of significance, while moving back and forth between theory and data applying a systemic combining approach (Dubois and Gadde, 2002). In the analysis, attention was brought to the processual development, collaborative constructs (Ford et al., 1986), and specifically to the university's role in the collaboration based on the accumulated findings. We here 
Table 1 Interviews

\begin{tabular}{|c|c|c|c|c|c|}
\hline Referred to as & Informant & Duration (minutes) & Organization & $\begin{array}{l}\text { Number of } \\
\text { employees }\end{array}$ & $\begin{array}{l}\text { Age of SME } \\
\text { (no. of years) }\end{array}$ \\
\hline R\&D project & Project leader R\&D & 50 & R\&D project & $\mathrm{N} / \mathrm{A}$ & N/A \\
\hline $\begin{array}{l}\text { Regional strategic } \\
\text { network (RSN) }\end{array}$ & $\begin{array}{l}\text { Regional strategic } \\
\text { network coordinator } \\
\text { (RSNC) also acting as } \\
\text { assistant project } \\
\text { leader R\&D }\end{array}$ & $20+20$ & $\begin{array}{l}\text { Regional strategic } \\
\text { network (RSN) }\end{array}$ & $\mathrm{N} / \mathrm{A}$ & $\mathrm{N} / \mathrm{A}$ \\
\hline Firm 1 & $\mathrm{R} \& \mathrm{D}$ manager & 45 & Solar collectors & 21 & 7 \\
\hline Firm 2 & CEO & 40 & Micro pumps & 6 & 16 \\
\hline Firm 3 & CEO & 40 & Vehicle movers & 24 & 35 \\
\hline Firm 4 & $\mathrm{R} \& \mathrm{D}$ manager & 30 & $\begin{array}{l}\text { Crimping systems for } \\
\text { electrical connectors }\end{array}$ & 155 & 88 \\
\hline Firm 5 & Site manager and CFO & 40 & Cutting dies & 30 & 67 \\
\hline Firm 6 & $\begin{array}{l}\text { CEO and } R \& D \\
\text { manager }\end{array}$ & $10+40$ & $\begin{array}{l}\text { Producer of aluminum } \\
\text { boats }\end{array}$ & 49 & 115 \\
\hline Firm 7 & Site manager & 55 & Heating systems & 19 & 25 \\
\hline Firm 8 & CEO & 45 & $\begin{array}{l}\text { Sawmills and cutting } \\
\text { tools }\end{array}$ & 35 & 26 \\
\hline Firm 9 & CEO & 20 & $\begin{array}{l}\text { Software for car } \\
\text { services }\end{array}$ & 8 & $\mathrm{~N} / \mathrm{A}$ \\
\hline Professor 1 & Professor & $20+20$ & $\begin{array}{l}\text { University } \\
\text { representative }\end{array}$ & $\mathrm{N} / \mathrm{A}$ & $\mathrm{N} / \mathrm{A}$ \\
\hline Professor 2 & Professor & 20 & $\begin{array}{l}\text { University } \\
\text { representative }\end{array}$ & $\mathrm{N} / \mathrm{A}$ & N/A \\
\hline
\end{tabular}

focused on the university's role and the SMEs' changed ways to innovate, dividing the consequences of the project into knowledge as innovations (knowledge that) and knowledge on innovating (knowledge how) and how knowledge was mobilized, combined, developed and managed (Gressetvold, 2001). During the analysis process, results were iterated between the two authors to extrapolate findings. In how data was collected by one author and initial analysis introduced by the other, we were able to expand on findings and discuss their relation to previous research, as well as the phenomenon of study in a way that allowed both integrations with and distance from the data (Merriam, 1998).

\section{Findings}

The RSN of the study intended to support SMEs located within a specific part of one of Sweden's 21 administrative regions. The geographical area is sparsely populated, encompassing only three small cities of about 10,000 inhabitants and the rural areas in between. Prior to the university collaboration, two small RSNs had run for decades but with limited success. The SMEs did not attend arranged RSN meetings to any greater extent, the meetings focusing on lectures on various topics and informal networking. The two RSNs were merged into one about three years ago to create new engagement. The idea was that more firms would create greater interest in network events and in the identification of new opportunities. The initial focus of the merged RSN was to assist SMEs in their staff recruitment efforts, especially of engineers, including activities such as visiting labor fairs at universities and inviting students to do degree projects at firm sites in collaboration with the SMEs. The administrative region awarded funding for three years. This project was seen as a success, facilitating the recruitment of engineers, but in other ways with limited benefits for the SMEs. An additional three years were recently granted.

\section{Formation of the university-regional strategic network project}

After the initial project, attention was directed toward business development and innovation. This initiative was headed by Firm 1, which had some previous university collaboration experience, but none where SMEs (rather than the university) had taken the lead in a project. Nine of the SMEs in the RSN joined this initiative, the rest resisting as:

- The project demanded time and resources for development work.

- There should be an innovation intention with sufficient exploratory scope to be relevant for involving university researchers, which implied a rather high risk of failure, so the SMEs had to be able to bear potential losses.

- Resources for administrative tasks, such as preparing reports to the funding organizations, were needed.

Most of the participating SMEs are active in international markets and feel pressure to develop new ideas, but while these SMEs were aware of the need for business development and innovation, their work to innovate was rather limited, reactive and often unstructured.

Project funding of approximately $€ 2.5 \mathrm{~m}$ was granted from European and Swedish funding agencies and with a focus on ideas up to prototype stages (thereby excluding any funding of market launches as similar). The project commenced in August 2018, the RSN hired a project manager and a university was 
contracted to support the SMEs in their innovation work. Three professors and two doctoral students ("the university representatives/researchers" below) represented the university and, in turn, consulted other university researchers when needed, such as metallurgists for SMEs needing that kind of expert knowledge in their development work. The university representatives have different areas of expertise within machine construction but shared an interest in innovation processes among SMEs. As stated by Professor 1, "our task is to support the firms' R\&D [research and development], mainly in terms of methods, but in parallel, we aim to study product development techniques in the context of SMEs because, in that area, there is a research gap" and Professor 2, based on his teaching about innovation to engineering students and pre-studies conducted, further explained the rationale for their interest: "the textbooks' content does not apply to small firms." The university representatives being experts in machine construction meant that they had particular interests in product and process innovation, with a high-structure focus on innovation processes.

\section{The university-regional strategic network collaboration} As for the structure of the project, the project leader gathers representatives from the SMEs in person twice a year to discuss and further plan the project's content in collaboration with the university representatives. Other meetings, lectures and seminars are held using the digital interactive tool Zoom, then focusing on the university-SME collaboration and allowing for around-the-clock access as these are recorded. The teaching part of the interaction is not intended to result in any course credits, diplomas or degrees for the participants; the focus is on firm development support, not on the individuals' educational curriculum. The course content for the lectures, and the basis for all the interaction, is the firms' needs and wishes, which were identified through dialogues at project start, as well as continuously during various types of meetings and interactions. They are thereby tailor-made for the firms in question, thus not following any traditional course or semester plan. Each lecture lasts about $1 \mathrm{~h}$, followed by about $30 \mathrm{~min}$ of questions and answers (Q\&A) for the SME representatives, focusing on the SMEs' ways of working and how they relate to the lecture content. During these Q\&A seminars, the SMEs obtain the chance to present and compare their ideas on innovation and how they currently and potentially will work with innovation.

As one of the main deliveries, a lecture series on innovation processes was conducted. This series concentrated on structures and methods on how to innovate, with the university representatives delivering lectures on such issues as market analysis and product development in terms of technical aspects, as well as innovation processes per se and including how to run such processes in a cost-efficient way and with the right input and tools for project management. This was the most theoretical part in that the lectures played a dominating part, although importantly being followed by discussion seminars relating the theory to practice. The university representatives being researchers in machine construction meant that they had quite a traditional, stage-wise notion on innovation processes from idea to commercialization, while they learnt as they went along from the SMEs about their conditions for innovating and emphasized the inclusion of market knowledge at early stages of the innovation processes. Another focus area for lectures was tools and methods for simulations. This part was more "hands on," as the university representatives demonstrated different simulation programs and made some simulations related to the SMEs' development work to show what type of results could be expected. A third focus was the internet of things (IoT), where a new lecture series focusing on IoT is planned. Some of the SMEs have implemented IoT and access a lot of data that can be used for further adaptions and innovation, while others wish to explore the potential of introducing IoT into their products. The SMEs, therefore, look for support in how to make the best of it, where the university representatives called for expertise to help the SMEs try our different kinds of sensors. Another topic is how to run and adapt processes at a distance, using the data, while considering data security. Various series of lecturers with follow-up seminars in this way were launched or planned related to innovation processes and to generic knowledge on new technology that would be adopted to each firm's needs and interests.

In addition to the lectures, there have, at the time of the interviews, been two meetings between the SMEs, the university representatives and the project leader for discussions on the firms' individual innovation work and thereby practices related to methods taught during the project. Furthermore, the university representatives support the SMEs' individual innovation projects and visit them or interact via Skype or telephone when needed, which has resulted in meetings about every second week. As explained by the representative of Firm 6: "we present our way of working and they give us advise and useful feedback on what is good and what can be done in other ways, based on research and how other firms act." This university support basically aims at improving the firms' innovation processes to facilitate the SMEs' development of innovations by each firm or by SMEs in conjunction.

\section{Outcomes of the university-regional strategic network collaboration}

The university collaboration project meant a change for the SMEs. While the RSN previously looked for broad topics for their meetings that could interest as many firms as possible, in the university collaboration project, the nine SMEs could focus on their individual innovation needs. Nevertheless, issues of interest to more than one SME were identified, which benefitted interaction and knowledge sharing among the SMEs. In the university-SME collaboration and inter-firm interaction among the SMEs, the university reached beyond a transfer of codified knowledge. By meeting in person but also during interaction using digital tools, the SMEs and the university transferred and developed tacit experiential knowledge in dialogues and discussions related to business development and innovation. Notably, the university has not exported its innovations to the SMEs. Rather, the university representatives act in a teaching role, transferring while concurrently learning to adapt relevant knowledge to the SMEs and simultaneously carrying out their own research aiming at improved recommendations for innovation processes for SMEs. Meanwhile, the SMEs interact during the seminars and, through themselves presenting their experiences to others, take on a teaching role as well. This, together with the continuous adaptation of the university representatives, advances the knowledge to be combined and developed. At the core was 
knowledge on structuring innovation processes specifically for SMEs-for-life, which, as can be read from Table 2, was also a primary outcome for the participating SMEs.

As Table 2 reveals, the SMEs developed knowledge on innovation processes, markets and market analyzes and simulations. The commonality among the various SMEs was that processes became more structured and systematic and thereby more proactive and strategic. The SMEs learnt how to include customer needs and simulate functionality before putting the product on the market. As a result, they have come to question their previous ways of working. A lack of knowledge on innovation processes among SMEs is typical and was common among the firms prior to the project: "most of them just worked ad hoc [...] I have seen that it is very strange many times, needs should be investigated before the concept is developed and so on," Professor 1 noted. This observation was sanctioned by firm representatives. During the project, a change was noted: "we used to develop first and then test in the market. Now, we can take a much broader perspective, consider how the market would react, how the product might be used [...]" (Firm 2) and, "we did not work very systematically, we mostly made adaptations to our customers' requests. Now, we aim to become more proactive, create customer offerings, forecast their needs and be a bit more at the frontline" (Firm 5). Firm 5 further notes, "the seminar series was interesting, we did not have that knowledge before" and Firm 7 points at that "without this project, we would have had to spend twice the time at least [...] and we would not have made simulations." The focus on the innovation process thereby enhanced the innovation skills of the SMEs and has, for instance, meant that Firm 7 received support in developing a simulation possibility for its innovation work, something the firm would not have thought of nor had the resources to organize itself, according to its site manager.

In addition to the intended knowledge development regarding business development and innovation, there were some major side effects for the SMEs (see the right-hand column in Table 2). Interaction, both in person and digitally, resulted in increased social networking. While social networking is often described as a core outcome of RSNs, this was social networking with a cause. It proved to be an important part of the project, with for some of the SMEs, sharing knowledge and experiences with other parties was a new experience and something that changed their mindset for the future. As stated by the CEO of Firm 4 in an interview on the RSN's home page (October 12, 2020), the interaction with other firms and university representatives led to a change in the company culture: "this project is about technologies that are new to us, so it became natural to turn to external sources and now there is a totally new acceptance for that, a cultural change has taken place." The representative of Firm 4, when asked what he had learned from taking part, answered: "that one should be pretty open to 'network' and talk to others, even if they are not within the same line of business. We have a lot in common regarding how to handle different questions [...] it does not take much time, but you may get a lot in return." Firm 1 commented, "it has been fascinating. To start with we seem to be so different, but then you start to talk and discover that we

Table 2 Outcomes of the RSN-university collaboration

\begin{tabular}{|c|c|c|c|}
\hline Firm & $\begin{array}{l}\text { Previous experience of } \\
\text { university interaction }\end{array}$ & Project results: main effects & Side effects \\
\hline 1 & $\begin{array}{l}\text { Yes, but wanted something on its } \\
\text { own terms }\end{array}$ & $\begin{array}{l}\text { Simulations of functionality increased } \\
\text { focus on market knowledge }\end{array}$ & Experienced networking synergies \\
\hline 2 & None & $\begin{array}{l}\text { Improved market analyzes and more } \\
\text { cost-efficient product development } \\
\text { processes }\end{array}$ & $\begin{array}{l}\text { Experienced that joint development } \\
\text { work is a win-win situation }\end{array}$ \\
\hline 3 & None & $\begin{array}{l}\text { Deeper knowledge in certain areas, also } \\
\text { about complex innovation processes }\end{array}$ & $\begin{array}{l}\text { Increased personal network facilitates } \\
\text { future cooperation and interaction }\end{array}$ \\
\hline 4 & None & $\begin{array}{l}\text { New perspectives on innovation } \\
\text { processes, a more proactive mindset } \\
\text { "We can test our ideas on the whole } \\
\text { group" }\end{array}$ & $\begin{array}{l}\text { Awareness of benefits of networking, } \\
\text { more likely to cooperate with other } \\
\text { actors } \\
\text { New acceptance for bringing in external } \\
\text { know-how - a cultural change }\end{array}$ \\
\hline 5 & None & $\begin{array}{l}\text { More systematic and proactive } \\
\text { innovation processes increased } \\
\text { digitalization }\end{array}$ & $\begin{array}{l}\text { Increased personal network facilitates } \\
\text { finding needed knowledge and speaking } \\
\text { partners }\end{array}$ \\
\hline 6 & Minor, some student projects & $\begin{array}{l}\text { Marketing analyzes } \\
\text { Adding services to customer offerings }\end{array}$ & $\begin{array}{l}\text { Further knowledge of other firms } \\
\text { facilitates future cooperation }\end{array}$ \\
\hline 7 & None & $\begin{array}{l}\text { Knowledge of simulation, improved } \\
\text { efficiency }\end{array}$ & $\begin{array}{l}\text { Awareness of benefits of networking } \\
\text { "University interaction has given us a } \\
\text { new perspective on our work" }\end{array}$ \\
\hline 8 & None & Improved efficiency in R\&D processes & $\begin{array}{l}\text { New and deepened relationships imply } \\
\text { an improved basis for further regional } \\
\text { cooperation }\end{array}$ \\
\hline 9 & None & $\begin{array}{l}\text { Too small to be able to participate, left } \\
\text { the project }\end{array}$ & \\
\hline
\end{tabular}


have the same kinds of problems, for instance, regarding product development. It has been very liberating to also hear about failures." The importance of this was, for example, explained by Firm 5: "in small firms, you are often rather alone in your role, so to have someone to discuss with or someone knowledgeable is very valuable [...] we need to increase our innovative capacity and hope to find ways for future collaboration on R\&D in the region." The SMEs' openness and generosity in sharing knowledge and experience impressed the project leader: "the atmosphere is really open, they are incredibly generous, I have really been impressed [. . . I think that they share the view that it benefits my firm if the region as a whole is doing fine" that is he believes that the SMEs are aware of the vulnerability of the sparsely populated region and its dependence on the future of each of its businesses. To summarize the outcome, three knowledge processes have been enhanced through the collaboration with the university:

1 The systematization of innovation processes.

2 The openness in taking and giving information among the SMEs.

3 The testing of ideas with customers.

\section{Discussion}

Most previous studies assume that the university should be the party to generate new ideas (Menzies, 2004; Bercovitz and Feldman, 2006) to be transferred to industry in the form of patents or startups (Aaboen et al., 2016; Aaboen et al., 2017; Laage-Hellman et al., 2019). While research is one of the university's core functions (Thursby and Thursby, 2011), the third mission of collaborating with industry for new businesses has created a conflict with both research and teaching (Wonglimpiyarat and Yuberk, 2006; Brostrom et al., 2021; Compagnucci and Spigarelli, 2020). In a non-traditional approach to university-industry collaboration, the collaboration between the university and the SMEs in the RSN as outlined in this paper did not deal with the sourcing of new ideas (or innovations) to industry (Etzkowitz and Leydesdorff, 2000; Bercovitz and Feldman, 2006), the facilitation of such innovations to incumbent firms (Moilanen et al., 2015) or the triple helix collaborations. Rather, and in terms of universityindustry collaborations for innovation, the paper reveals a unique role that has previously not been extensively explored in research: how the university maintains a teaching role in universityindustry collaboration. This means that the university representatives preserved one of the university's core functions (Thursby and Thursby, 2011) and thereby could avoid some of the role collisions referred to in previous research. In this case, the university representatives combined this with the other core function: researching about SMEs' innovation processes. Painted toward a background of SMEs-for-life in a sparsely populated area of Sweden, the paper helps grasp how university-industry collaboration for innovation would be contextualized in a continuous adjustment to the SMEs' particular circumstances (Asheim and Coenen, 2006; Cai, 2015).

\section{The innovations}

The innovations developed by the SMEs were generally product-based, including advancing features (such as the integration with IoT) of current products. While following an innovation process from idea generation onwards, they were also characterized by how the project had facilitated market intelligence skills, adhered to developments in the market and indicated enhanced skills of innovating, reflected in the practice of knowledge (Blackler, 1995; Nonaka and von Krogh, 2009). The advanced orientation to interaction also had a part to play as it made the SMEs more responsive to customer input (Gassmann et al., 2010; Öberg and Alexander, 2019) and in the innovation process: to test out new ideas with the market. As a form of open innovation, this, though, mainly had to do with inbound innovations based on input from customers and partly with collaborative innovations with other SMEs (Öberg and Alexander, 2019). The teaching in the project focusing on methods indicates how knowledge on innovating could be kept on a level that allowed it to be transferred by the SMEs from one innovation and interaction to the next. This again stresses that while innovations as objects were an outcome for the SMEs and RSN, the project and university involvement focused on skill developments.

\section{The teaching role}

As research reveals, teaching can be conducted in many different ways (Ball et al., 2008; Bager, 2011; Snihur et al., 2021 on traditional and emerging teaching roles), and the case points at how the university representatives mixed various teaching roles, namely, lecturing, coaching and activating the SME representatives in the SMEs' innovation processes. This means that the teaching was both unidirectional and interactive, where no teaching was conducted without a reflexive discussion following it. Furthermore, the university had some of the SME representatives telling about their experience in a way that draws attention to the flippedclassroom practices. The lecturing allowed for the teaching of the structured innovation processes, while the remaining activities were much about engaging the SMEs in a learningby-doing kind of way. While the teaching carries some similarities with how innovation using such pedagogics as design thinking has increasingly become taught at universities (Glen et al., 2015; John et al., 2020), the, perhaps, most important part of the teaching was what happened "off scene:" in how the SMEs practiced those skills achieved in their real-life context, meaning a lengthy activation of those taking part in the teaching activities. Importantly here was how the SMEs from the start had voluntarily committed to the project.

Beyond how the teaching was conducted is what type of knowledge was transferred and how it was combined and developed. The knowledge, thus, focused on how to innovate, rather than on knowledge that (Nonaka and Takeuchi, 1995), which would have been associated with the university actually producing the innovations. Knowledge on how to innovate indicates knowing or knowledge as skills (Blackler, 1995; Nonaka and von Krogh, 2009) and is distinctly different from how the university "places" innovations in the business context and RSN literature's description of innovations as objects (de Wit-de Vries et al., 2019). Based on how the skill of innovating was in focus with structured innovation processes as a core message, the skills would in the second circle of knowledge be practiced by the SMEs in their innovation processes and lead to the production of new ideas that is knowledge as objects. Figure 1 depicts the various types of knowledge modifications as circles 
Figure 1 Knowledge circles of innovating and innovation based on the university's teaching role

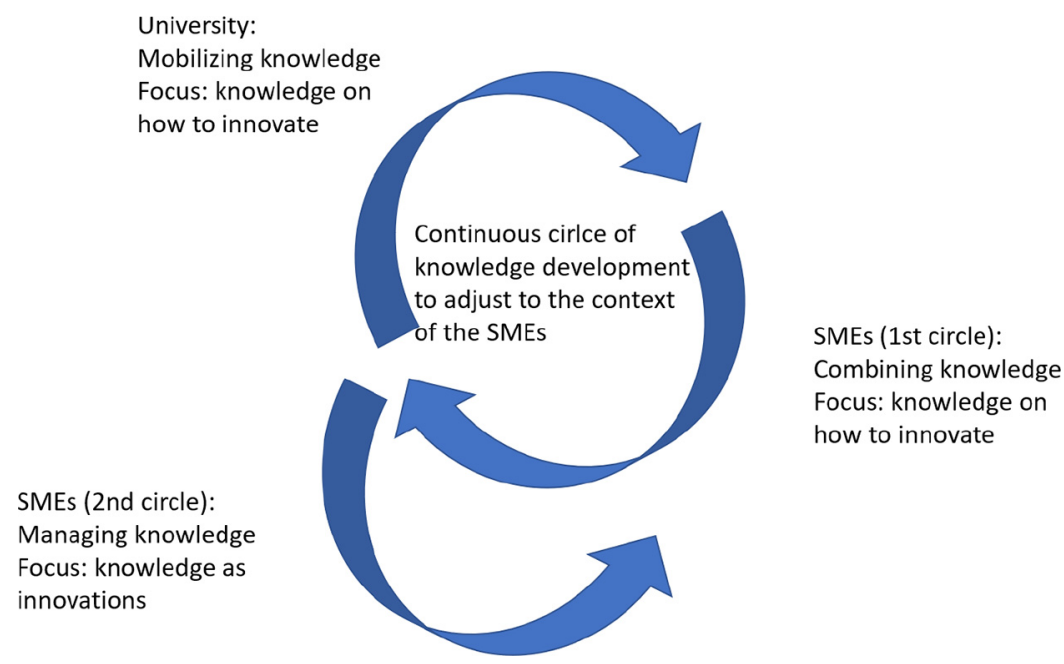

entailing knowledge on innovating (first circle) and knowledge as innovation (second circle).

Knowledge as skills rather than facts or objects means that knowledge as a resource (Penrose, 1959) is modified to make it relevant for the context in which it is to be used (Gressetvold, 2001). It thereby allows the SMEs (and industry) to practice and develop new innovations, while the prevailing focus in university-industry collaborations only means that the university places innovations in the industry context. The chain of knowledge in the present study can be understood as to how the university mobilized knowledge, which was developed in the interactive process of the project as it was combined with contextual knowledge of the SMEs. For the SMEs particularly, the combination of knowledge was how they integrated the knowledge on innovating with their particular circumstances (for example, line of business, type of markets, Benner and Tushman, 2003; Asheim and Coenen, 2006; Garud et al., 2014). This then, as the more structured, systematic and proactive processes were practiced as a means of managing knowledge, was focused on creating new business ideas and innovations by the SMEs, as the second circle in Figure 1. As part of the knowledge development, the SMEs learnt skills on how to interact more pronouncedly with others - described as a cultural change - which not only led to the "social networking for a cause" (compared to how previous studies on RSNs have concluded that they rarely reach beyond social networking as such or social networking without a cause; Eklinder-Frick, 2015) but also to how innovation processes came to entail increased inclusion of customers, for instance (Gassmann et al., 2010), hence opening the circle of innovations. These circles of knowledge and their related knowledge as a resource to, for instance, transfer, develop and combine, indicate a pattern, which extends from how the university in the universityindustry collaboration acted a different role than generally is expected related to innovation, the very design of the teaching with structured, lectured knowledge falling out in structured innovation processes, while the activation of the SMEs led to the second circle of knowledge as facts demonstrated in their actual innovations.

\section{Conclusions}

This paper describes and discusses the university's teaching role and its consequences in university-industry collaborations for innovations. In the theory section, the following questions were raised, namely, how can the university's teaching role in university-industry collaborations be understood? What are the consequences of the university taking on a teaching role for innovation?

The teaching role is one of transferring skills related to innovation processes, and hence, knowledge as to how to perform tasks. The SMEs were then the parties to adopt these skills to their own circumstances, and as a later stage, practice this knowledge with resulting new innovations. The teaching role demonstrates a mix of lecturing, coaching and activating, where the latter activities link directly to the SMEs' actual production of innovations. The consequences were more structured, systematic and proactive innovation processes, replacing ad hoc customer adaptations and as an unexpected consequence: increased openness toward other firms, described in terms of increased social networking with a cause. Hence, the university inclusion outcome was tangible changes in innovation processes and intangible, cognitive changes in attitudes to openness and inter-firm collaboration. These latter changes will likely continue to impact the knowledge development strategies of the SMEs (Gulati et al., 2000), and during the project, they presented themselves as trust was created. The sharing of issues with others and activities focusing on generic processes of innovating while the project tackled capability issues of the individual firms created an almost therapeutical atmosphere that helped create trust and openness.

By pointing out universities' teaching role, the paper makes an important distinction between knowledge on innovating (knowledge how) and innovation knowledge per se (knowledge that). The latter would assume that the university would be the party to provide innovative ideas as previously seen in studies on university startups and open innovation initiatives aimed to support incumbent firms with new ideas (Aaboen et al., 2016; La Rocca et al., 2016; Aaboen et al., 2017). Meanwhile, 
knowledge on innovating means that the university remains with one of its core functions: to teach (Thursby and Thursby, 2011). This has as a consequence that the industry parties learn how to innovate, rather than relying on universities for sourcing innovations. Our findings thereby point at the need to reconsider what roles universities should play in any universityindustry collaborations while pointing to how each party should rather keep up with its core tasks than extend these to new ones. This is, namely, also evident among the participating SMEs in the RSN: they adjusted their processes along with the scheme of learning to become more systematic in work with innovations and customer interaction, and through trust creation, they became more open. Still, the SMEs remained with what they knew the best: how to run their individual businesses in such business contexts that were not limited by the RSN or in other ways in space.

The circles of knowledge and how various teaching practices are interlinked with types of knowledge and the transfer, combination and development makes a theoretical contribution to studies on university-industry collaborations focusing on innovations. The assumption that universities should be sources of new ideas is questioned, while this hampers the collision (Thursby and Thursby, 2011) with universities' core functions. To research on university-industry collaborations, this paper thereby emphasizes the university's role as a facilitator of knowledge on innovation processes and presents the model of circles of knowledge in university-industry collaborations (Figure 1). Empirically, the university-RSN collaboration makes an important contribution, also acknowledging the limited attention paid to SMEs in university-industry studies (Christensen, 1997, in Corral de Zubielqui et al., 2015; Miller et al., 2016; Rosendo-Rios et al., 2016) and the rare existence of SMEs in such collaborations in practice.

\section{Practical implications}

The most important practical implication of this paper, therefore, is the need to rethink university-industry collaborations and policies related to expectations among parties and role divisions. Universities should here put into action plans to work on teaching innovations and thereby support firms to accomplish development in their contexts rather than be the innovators in collaborations with industry. Focusing on teaching, SMEs (and potentially other firms) benefit from university collaborations by learning about best practices and process thinking. Considering the potential gains, public fund providers should pay attention to this means of supporting university-industry collaboration in general and university-RSN collaboration, in particular, to thereby facilitate the future development of economically less competitive regions while reconsidering the universities' roles in such endeavors. The same applies for policies on university-industry collaborations: these should be reconsidered to allow and support industry to develop innovation skills rather than relying on universities for the provision of innovations.

For SMEs-for-life and RSNs, the paper points at how SMEs may benefit from the collaboration with universities, while the specific case also indicates how the initiative, being driven by an SME and based on voluntary commitment, helped to realize its goals. A group of SMEs, such as those in the RSN, may be more attractive and resourceful as a partner than single SMEs, not the least as an RSN may imply possibilities of financial support from public fund providers.

For universities, adopting pedagogics that activates recipients and provides generic but also contextualized knowledge - while emphasizing how those receiving the knowledge should practice it - are important takeaways from this paper. More precisely, the teaching should:

- Be adjusted to recipients so as a mutual benefit is articulated.

- Avoid the taking-over of the practice of skills.

- See learning through practice as a core of teaching.

- Establish new content as the teaching goes along, while continuously practicing the teaching of processes rather than of specific innovations.

\section{Limitations and suggestions for further research}

The findings are based on data from a single case in a specific setting of heterogeneous SMEs, mostly lacking experience of university-industry collaboration and situated in a sparsely populated region. While the university's teaching role expects to be relevant for other university-industry collaborations focusing on innovations, further studies would need to prove that point. In the study, one of the SMEs with previous university interaction experience was an important driving force behind the creation of the project. This indicates that such experiences may pave the way for further collaborations among universities and SMEs. The roles of champions, like that firm related to university-RSN collaborations, would be of interest to study further.

In addition to continuing to follow the particular universityRSN project described in this paper, additional studies should focus on RSNs of different types (such as those being formed around a specific industry and those being denser than the present one), RSNs created on a less voluntary bases and RSNs containing various types of SMEs. University representatives with various backgrounds would be of interest to study in situations similar to the one of study here as the machine construction researchers would have had a particular focus on product innovations and structured processes. Continuing to study the present project would allow us to capture long-term effects and see whether and how initiatives and roles change throughout the project. Furthermore, the university as a source for knowledge on innovating would be interesting to explore in other settings, as would to theorize further on innovating as compared to innovations per se, running from incremental to radical innovations.

\section{References}

Aaboen, L., La Rocca, A., Lind, F., Perna, A. and Shih, T., Eds (2017), Starting up in Business Networks: Why Relationships Matter in Entrepreneurship, London, Palgrave.

Aaboen, L., Laage-Hellman, J., Lind, F., Öberg, C. and Shih, T. (2016), "Exploring the roles of university spin-offs in business networks", Industrial Marketing Management, Vol. 59, pp. 157-166.

Agrawal, A.K. (2001), "University-to-industry knowledge transfer: literature review and unanswered questions", 
International fournal of Management Reviews, Vol. 3 No. 4, pp. 285-302.

Alexander, A.T., Martin, D. and Bessant, J. (2011), "Which intermediaries for open innovation? Toward a conceptual platform of strategy, core competences and service channels", 4th Annual ISPIM Symposium, Wellington, Wiley Higher Education.

Andrésen, E., Lundberg, H. and Roxenhall, T. (2012), "Designing for commitment in regional strategic networks", Management Research Review, Vol. 35 No. 6, pp. 531-552.

Ankrah, S. and Omar, A.T. (2015), "Universities-industry collaboration: a systematic review", Scandinavian fournal of Management, Vol. 31 No. 3, pp. 387-408.

Asheim, B.T. and Coenen, L. (2006), "Contextualising regional innovation systems in a globalising learning economy: on knowledge bases and institutional frameworks", The fournal of Technology Transfer, Vol. 31 No. 1, pp. 163-173.

Bager, T. (2011), "The camp model for entrepreneurship teaching", International Entrepreneurship and Management fournal, Vol. 7 No. 2, pp. 279-296.

Ball, D.L., Thames, M.H. and Phelps, G. (2008), "Content knowledge for teaching: what makes it special?”, fournal of Teacher Education, Vol. 59 No. 5, pp. 389-407.

Baraldi, E., Gressetvold, E. and Harrison, D. (2012), "Resource interaction in inter-organizational networks: foundations, comparison, and a research agenda", Fournal of Business Research, Vol. 65 No. 2, pp. 266-276.

Benner, M. and Tushman, M.L. (2003), "Exploitation, exploration, and process management: the productivity dilemma revisited", Academy of Management Review, Vol. 28 No. 2, pp. 238-256.

Berbegal-Mirabent, J., Gil-Domenech, D. and RibeiroSoriano, D.E. (2020), "Fostering university-industry collaborations through university teaching", Knowledge Management Research E Practice, Vol. 18 No. 3, pp. 263-275.

Bercovitz, J. and Feldman, M. (2006), "Entrepreneurial universities and technology transfer: a conceptual framework for understanding knowledge-based economic development", The Fournal of Technology Transfer, Vol. 31 No. 1, pp. 175-188.

Bessant, J., Alexander, A.T., Rush, H., Tsekouras, G. and Lamming, R.C. (2012), "Constructing learning advantage through networks", fournal of Economic Geography, Vol. 12 No. 5, pp. 1087-1112.

Bjerregaard, T. (2009), "Universities-industry collaboration strategies: a micro-level perspective", European fournal of Innovation Management, Vol. 12 No. 2, pp. 161-176.

Blackler, F. (1995), "Knowledge, knowledge work and organizations: an overview and interpretation", Organization Studies, Vol. 16 No. 6, pp. 1021-1046.

Boschma, R.A. (2005), "Proximity and innovation: a critical assessment”, Regional Studies, Vol. 39 No. 1, pp. 61-74.

Brostrom, A., Buenstorf, G. and McKelvey, M. (2021), "The knowledge economy, innovation and the new challenges to universities: introduction to the special issue", Innovation, Organization E Management, Vol. 23 No. 2, pp. 145-162.

Cai, Y. (2015), "What contextual factors shape 'innovation in innovation'? Integration of insights from the triple helix and the institutional logics perspective", Social Science Information, Vol. 54 No. 3, pp. 299-326.
Christensen, C.M. (1997), The Innovator's Dilemma: When New Technologies cause Great Firms to Fail, Harvard Business School Press, Boston, MA.

Cohen, W. and Levinthal, D. (1990), "Absorptive capacity: a new perspective on learning and innovation", Administrative Science Quarterly, Vol. 35 No. 1, pp. 128-152.

Compagnucci, L. and Spigarelli, F. (2020), "The third mission of the university: a systematic literature review on potentials and constraints", Technological Forecasting E Social Change, Vol. 161 .

Cook, S. and Brown, J. (1999), "Bridging epistemologies: the generative dance between organizational knowledge and organizational knowing", Organization Science, Vol. 10 No. 4, pp. 381-400.

Corral de Zubielqui, G.C., Jones, J., Seet, P.S. and Lindsay, N. (2015), "Knowledge transfer between actors in the innovation system: a study of higher education institutions (HEIS) and SMEs", Fournal of Business \& Industrial Marketing, Vol. 30 Nos 3/4, pp. 436-458.

Cunningham, J.A. and Link, A.N. (2015), "Fostering university-industry $\mathrm{R} \& \mathrm{D}$ collaborations in european union countries", International Entrepreneurship and Management fournal, Vol. 11 No. 4, pp. 849-860.

Cyert, R.M. and Goodman, P.S. (1997), "Creating effective university-industry alliances: an organizational learning perspective", Organizational Dynamics, Vol. 25 No. 4, pp. 45-58.

de Wit-de Vries, E., Dolfsma, W.A., van der Windti, H.J. and Gerkema, M.P. (2019), "Knowledge transfer in universityindustry research partnerships: a review", The fournal of Technology Transfer, Vol. 44 No. 4, pp. 1236-1255.

Dubois, A. and Araujo, L. (2004), "Research methods in industrial marketing studies", in Håkansson, H., Harrison, D. and Waluszewski, A. (Eds), Rethinking Marketing: Developing a New Understanding of Markets, Chichester, John Wiley \& Sons: 207-227.

Dubois, A. and Gadde, L.E. (2002), "Systematic combining: an abductive approach to case research", fournal of Business Research, Vol. 55 No. 7, pp. 553-560.

Eisenhardt, K.M. (1989), "Building theories from case study research", The Academy of Management Review, Vol. 14 No. 4, pp. 532-550.

Eklinder-Frick, J.O. (2015), "Development, production and use in policy initiated innovation", fournal of Business $\mathcal{G}$ Industrial Marketing, Vol. 30 No. 8, pp. 973-986.

Eklinder-Frick, J. and Åge, L.J. (2017), "Perspectives on regional innovation policy-from new economic geography towards the IMP approach", Industrial Marketing Management, Vol. 61, pp. 81-92.

Eklinder-Frick, J., Eriksson, L.T. and Hallén, L. (2011), "Bridging and bonding forms of social capital in a regional strategic network", Industrial Marketing Management, Vol. 40 No. 6, pp. 994-1003.

Eklinder-Frick, J., Eriksson, L.T. and Hallén, L. (2014), "Multidimensional social capital as a boost or a bar to innovativeness", Industrial Marketing Management, Vol. 43 No. 3, pp. 460-472.

Etzkowitz, H. and Leydesdorff, L. (2000), "The dynamics of innovation: from national systems and 'mode 2 ' to a triple helix of university-industry-government relations", Research Policy, Vol. 29 No. 2, pp. 109-123. 
Ford, D., Håkansson, H. and Johansson, J. (1986), "How should companies interact?", Industrial Marketing and Purchasing, Vol. 1 No. 1, pp. 26-41.

Friedman, J. and Silberman, J. (2003), "University technology transfer: do incentives, management, and location matter?", The fournal of Technology Transfer, Vol. 28 No. 1, pp. 17-30.

Gadde, L.E. (2004), "Activity coordination and resource combining in distribution networks - implications for relationship involvement and the relationship atmosphere", fournal of Marketing Management, Vol. 20 Nos 1/2, pp. 157-184.

Gao, H., Ding, X.H. and Wu, S. (2020), "Exploring the domain of open innovation: bibliometric and content analyses", fournal of Cleaner Production, Vol. 275.

Garud, R., Gehman, J. and Giuliani, A.P. (2014), "Contextualizing entrepreneurial innovation: a narrative perspective”, Research Policy, Vol. 43 No. 7, pp. 1177-1188.

Gassmann, O., Enkel, E. and Chesbrough, H.W. (2010), "The future of open innovation", R\&D Management, Vol. 40 No. 3, pp. 213-221.

Glen, R., Suciu, C., Baughn, C.C. and Anson, R. (2015), "Teaching design thinking in business schools", The International fournal of Management Education, Vol. 13 No. 2, pp. 182-192.

Gressetvold, E. (2001), Technical Development within the Industrial Network Approach as Interaction between Four Resource Entities, IMP Conference, Oslo.

Guercini, S. and Tunisini, A. (2017), "Formalizing in business networks as a tool for industrial policy", IMP fournal, Vol. 11 No. 1, pp. 91-108.

Gulati, R., Nohria, N. and Zaheer, A. (2000), "Strategic networks", Strategic Management fournal, Vol. 21 No. 3, pp. 203-215.

Halinen, A. and Törnroos, J.Å. (1998), "The role of embeddedness in the evolution of business networks", Scandinavian Fournal of Management, Vol. 14 No. 3, pp. 187-205.

Halinen, A. and Törnroos, J.Å. (2005), "Using case methods in the study of contemporary business networks", fournal of Business Research, Vol. 58 No. 1, pp. 1287-1297.

Heirati, N. and Siahtiri, V. (2019), "Driving service innovativeness via collaboration with customers and suppliers: evidence from business-to-business services", Industrial Marketing Management, Vol. 78, pp. 6-16.

Huber, G.P. and Power, D.J. (1985), "Retrospective reports of strategic-level managers: guidelines for increasing their accuracy", Strategic Management fournal, Vol. 6 No. 2, pp. 171-180.

Huggins, R. and Johnston, A. (2009), "Knowledge networks in an uncompetitive region: SME innovation and growth", Growth and Change, Vol. 40 No. 2, pp. 227-259.

Hughes, T., O'Regan, N. and Sims, M.A. (2009), "The effectiveness of knowledge networks: an investigation of manufacturing SMEs", Education + Training, Vol. 51 Nos 8/9, pp. 665-681.

John, P.K., Lear, E., Decosta, P.L.E., Gregor, S., Dann, S. and Sun, R. (2020), "Designing a visual tool for teaching and learning front-end innovation", Technology Innovation Management Review, Vol. 10 No. 9, pp. 16-26.
La Rocca, A., Öberg, C. and Hoholm, T. (2016), "When startups shift network-notes on start-ups journey", in Aaboen, L., La Rocca, A., Lind, F., Perna, A. and Shih, T., Starting up in Business Networks: Why Relationships Matter in Entrepreneurship.

Laage-Hellman, J., Lind, F., Öberg, C. and Shih, T. (2019), Interaction between University Spin-Offs and Academia following Commercialization, IMP Forum. Uppsala.

Laursen, K. and Salter, A. (2004), "Searching high and low: what types of firms use universities as a source of innovation?", Research Policy, Vol. 33 No. 8, pp. 1201-1215.

Linton, J.D. and $\mathrm{Xu}, \mathrm{W}$. (2021), "Research on science and technological entrepreneurship education: what needs to happen next?", The fournal of Technology Transfer, Vol. 46 No. 2, pp. 393-406.

Lorenzoni, G. and Baden-Fuller, C. (1995), "Creating a strategic center to manage a web of partners", California Management Review, Vol. 37 No. 3, pp. 146-163.

Lundberg, H. (2013), "Triple helix in practice: the key role of boundary spanners", European fournal of Innovation Management, Vol. 16 No. 2, pp. 211-226.

Lundberg, H. and Öberg, C. (2021), "The matter of locality: family firms in sparsely populated regions", Entrepreneurship and Regional Development.

Lundberg, H. and Johanson, M. (2011), Network Strategies for Regional Growth, in H. Lundberg and M. Johanson, Network Strategies for Regional Growth, London, Palgrave Macmilian: 1-21.

McCracken, G. (1988), The Long Interview, Newbury Park, Sage Publications.

Malecki, E.J. (2007), "Cities and regions competing in the global economy: knowledge and local development policies", Environment and Planning C: Government and Policy, Vol. 25 No. 5, pp. 638-654.

Mathisen, M. and Rasmussen, E. (2019), "The development, growth, and performance of university spin-offs: a critical review", The fournal of Technology Transfer, Vol. 44 No. 6, pp. 1891-1938.

Menzies, T.V. (2004), "Are universities playing a role in nurturing and developing high-technology entrepreneurs? The administrators' perspective", The International fournal of Entrepreneurship and Innovation, Vol. 5 No. 3, pp. 149-157.

Merriam, S.B. (1998), Qualitative Research and Case Study Applications in Education, San Francisco, Jossey-Bass.

Miles, M. and Huberman, M.A. (1984), Qualitative Data Analysis: A Source Book of New Methods, Newbury Park, Sage Publications.

Miller, K., Puthusserry, P., McAdam, R., Moffett, S. and Alexander, A. (2016), "Knowledge transfer in university quadruple helix ecosystems: an absorptive capacity perspective", RED Management, Vol. 46 No. 2, pp. 383-399.

Miranda, F., Chamorro, A. and Rubio, S. (2018), "Rethinking university spin-off: a critical literature review and a research agenda", The fournal of Technology Transfer, Vol. 43 No. 4, pp. 1007-1038.

Moilanen, H., Halla, M. and Alin, P. (2015), "Openness in university-industry collaboration: probing managerial perceptions", European fournal of Innovation Management, Vol. 18 No. 4, pp. 493-507. 
Möller, K. and Rajala, A. (2007), "Rise of strategic nets - new modes of value creation", Industrial Marketing Management, Vol. 36 No. 7, pp. 895-908.

Nonaka, I. and Takeuchi, H. (1995), The Knowledge Creating Company: How Japanese Companies Create the Dynamics of Innovation, New York, NY, Oxford University Press.

Nonaka, I. and von Krogh, G. (2009), "Tacit knowledge and knowledge conversion: controversy and advancement in organizational knowledge creation theory", Organization Science, Vol. 20 No. 3, pp. 635-652.

Nutt, P.C. (1986), "Tactics of implementation", Academy of Management fournal, Vol. 29 No. 2, pp. 230-261.

Öberg, C. (2010), "Customer roles in innovations", International fournal of Innovation Management, Vol. 14 No. 6, pp. 989-1011.

Öberg, C. and Alexander, A. (2019), "The openness of open innovation in ecosystems - integrating innovation and management literature on knowledge linkages", fournal of Innovation E Knowledge, Vol. 4 No. 4, pp. 211-218.

Penrose, E.T. (1959), The Theory of the Growth of the Firm, Oxford, Basil Blackwell.

Persson, S.G., Lundberg, H. and Andresen, E. (2011), "Interpartner legitimacy in regional strategic networks", Industrial Marketing Management, Vol. 40 No. 6, pp. 1024-1031.

Pettigrew, A.M. (1973), The Politics of Organizational Decision Making, London, Tavistock.

Pettigrew, A.M. (1997), "What is a processual analysis?", Scandinavian fournal of Management, Vol. 13 No. 4, pp. 337-348.

Rosendo-Rios, V., Ghauri, P. and Zhang, Y. (2016), "Empirical analysis of the key factors that can contribute to university-industry cooperational success from a relationship marketing approach", European fournal of International Management, Vol. 10 No. 6, pp. 647-677.

Rothaermel, F.T. and Hess, A.M. (2007), "Building dynamic capabilities: innovation driven by individual-, firm-, and network-level effects", Organization Science, Vol. 18 No. 6, pp. 898-921.

Saxenian, A. (1990), "Regional networks and the resurgence of silicon valley", California Management Review, Vol. 33 No. 1, pp. 89-112.

Siegel, D., Waldman, D. and Link, A. (2003), “Assessing the impact of organizational practices on the relative productivity of university technology transfer offices: an exploratory study", Research Policy, Vol. 32 No. 1, pp. 27-48.
Snihur, Y., Lamine, W. and Wright, M. (2021), "Educating engineers to develop new business models: exploiting entrepreneurial opportunities in technology-based firms", Technological Forecasting E Social Change, Vol. 164.

Soetanto, D.P. and Jack, S.L. (2013), "Business incubators and the networks of technology-based firms", The fournal of Technology Transfer, Vol. 38 No. 4, pp. 432-453.

Striukova, L. and Rayna, T. (2015), "University-industry knowledge exchange an exploratory study of open innovation in UK universities", European fournal of Innovation Management, Vol. 18 No. 4, p. 471.

Thorpe, R., Holt, R., Macpherson, A. and Pittaway, L. (2005), "Using knowledge within small and medium-sized firms: a systematic review of the evidence", International fournal of Management Reviews, Vol. 7 No. 4, pp. 257-281.

Thursby, J.G. and Thursby, M.C. (2011), "Has the Bayh-Dole act compromised basic research", Research Policy, Vol. 40 No. 8, pp. 1077-1083.

Von Hippel, E. (2001), "Innovation by user communities: learning from open-source software", MIT Sloan Management Review, Vol. 42 No. 4, pp. 82-86.

Watfa, M.K. and Audi, D.M. (2015), "New learning methodologies using modern technologies", International fournal of Innovation and Learning, Vol. 17 No. 3, pp. 275-297.

Welch, C., Piekkari, R., Plakoyiannaki, E. and PaavilainenMäntymäki, E. (2011), "Theorising from case studies: towards a pluralist future for international business research", fournal of International Business Studies, Vol. 42 No. 5, pp. 740-762.

Wonglimpiyarat, J. and Yuberk, N. (2006), "Successes and failures in managing innovations: bridging the interface between technology and business", International fournal of Technology, Policy \& Management, Vol. 6 No. 1, pp. 5-5.

$\mathrm{Xu}, \mathrm{K}$., Huang, K.F. and Xu, E. (2014), "Giving fish or teaching to fish? An empirical study of the effects of government research and development policies", RED Management, Vol. 44 No. 5, pp. 484-497.

Yin, R.K. (1994), "Case study research - Design and methods", Thousand Oaks, Sage Publications, Inc.

Zhou, K.Z. and Wu, F. (2010), "Technological capability, strategic flexibility, and product innovation", Strategic Management fournal, Vol. 31 No. 5, pp. 547-561.

\section{Corresponding author}

Christina Öberg can be contacted at: christina.oberg@kau.se 